\title{
Efektivitas Konseling Informasi Edukasi Terhadap Pengetahuan Wanita Usia Subur Tentang Kanker Servik dan Inspeksi Visual Asam Asetat Sebagai Deteksi Dini
}

\author{
Cut Adeya Adella ${ }^{1, a^{*}}$, Nur Asnah Sitohang ${ }^{2, b}$ \\ ${ }^{1}$ Fakultas Kedokteran, Universitas Sumatera Utara, Medan 20155, Indonesia \\ ${ }^{2}$ Fakultas Keperawatan, Universitas Sumatera Utara, Medan 20155, Indonesia \\ a cutadeya.adella@ gmail.com *; b ${ }^{\text {nur75asnah@ yahoo.co.id }}$ \\ * corresponding author
}

ARTICLE INFO

Keywords

Cervical cancer

Women of childbearing age

IVA Test

\section{ABSTRACT}

Cervical cancer is cancer that occurs in the cervix, an area in the female reproductive organs which is the entrance to the uterus, located between the uterus and the intercourse or vagina. The main cause of cervical cancer is Human Papilloma Virus (HPV) infection. Cervical cancer usually attacks women aged 35-55 years. Visual Inspection with Acetic Acid (IVA) is a visual inspection of the cervix using vinegar with the eye to detect abnormalities after applying 3-5\% vinegar. This community service aims to: (1) provide communication, education and information (IEC) about cervical cancer and the benefits of IVA Test, (2) conduct IVA Test, (3) measure the knowledge of women of childbearing age about cervical cancer and IVA test. Implemented at Klinik Bersalin Sari Medan (30 people). Data analysis using Wilcoxon test. The results of the activity obtained the majority of data aged 37-39 years (43.3\%), Javanese (40\%), Islamic religion (90\%), first married age 21-23 years (43.3\%), the number of births 3 times (30\%), the IVA test results are negative (90\%), inflammation / cervicitis (10\%). The knowledge before being given Information Education Communication (IEC) averaged $=14.57 ; \mathrm{SD}=3,633$ and after being given IEC average $=23.60$, $\mathrm{SD}=1,589$. Statistical test results obtained mean difference $=9.03$ and $\mathrm{P}$ value $=0.001$, it can be concluded that there is a significant influence of IEC on women of childbearing age knowledge about cervical cancer and IVA tests. It is recommended to midwives to socialize the benefits of IVA tests and carry them out as early detection of cervical cancer.

\section{Pendahuluan}

Metode pemeriksaan IVA merupakan suatu metode pemeriksaan kanker leher rahim secara murah dan mudah dikerjakan, tetapi juga mempunyai akurasi hasil yang tinggi dengan menggunakan cairan asam asetat melalui usap serviks dengan asam cuka 3-5\%. Keuntungan dari pemeriksaan test IVA adalah hasil segera diketahui, efektif, aman, praktis, teknik pemeriksaan sederhana, bahan dan alat yang sederhana dan murah, sensitivitas dan spesifikasitas cukup tinggi, dapat dilakukan oleh semua tenaga medis terlatih [1].

Kanker serviks adalah kanker yang terdapat pada leher rahim, yaitu area bagian bawah rahim yang menghubungkan rahim dengan vagina yang disebabkan Human Papilloma Virus (HPV).Terjadi jika sel-sel serviks menjadi abnormal dan membelah secara tidak terkendali [2].

Di Indonesia, insiden kanker serviks diperkirakan \pm 40.000 kasus pertahun dan masih merupakan kanker wanita yang tersering [3]. Penelitian Wijaya (2010) pada tahun 2009, kasus baru kanker serviks berjumlah 2.429 atau sekitar $25,91 \%$ dari seluruh kanker yang ditemukan di Indonesia. Dengan angka kejadian ini, kanker leher rahim menduduki urutan kedua setelah kanker payudara pada wanita usia subur 15-44 tahun [4]. 
Program yang dilaksanakan mempunyai mitra yaitu Klinik Bersalin Sari Kelurahan Teladan Barat Kecamatan Medan Kota (Mitra 2). Berdasarkan pengamatan dan wawancara kepada mitra mereka menyatakan permasalahnnya sebagai berikut: (1) Di Indonesia kanker serviks menduduki peringkat pertama, 65\% kondisi pasiennya dalam stadium lanjut; (2) Pengetahuan wanita usia subur tentang kanker serviks masih rendah, (3) WUS dilingkungan mitra masih banyak yang belum pernah dilakukan tes IVA, (4) Upaya sosialisasi kanker serviks dan pentingnya dilakukan deteksi dini dengan tes IVA juga belum rutin dilakukan karena keterbatasan tenaga dan waktu.

\section{Metode}

Berdasarkan permasalahan yang telah dikemukakan, maka dalam kegiatan ini metode yang digunakan adalah : (1) Pre test tujuannya untuk mengidentifikasi pengetahuan WUS terhadap kanker serviks dan tes IVA; (2) Melakukan komunikasi, informasi, dan edukasi (KIE) tentang kanker serviks dan tes IVA ; (3) Post test ujuannya untuk mengidentifikasi pengetahuan WUS terhadap kanker serviks dan tes IVA; (4) Melatih bidan praktek disekitar mitra mahir melakukan tes IVA dan menginterpretasi hasilnya; (5) Menganalisis data kuesioner dengan Wilcoxon test.

\section{Hasil dan Diskusi}

Tabel 1. Karakteristik data demografi responden

\begin{tabular}{|c|c|c|}
\hline Data Demografi & Frekuensi (f) & Persentase (\%) \\
\hline $\begin{array}{c}\text { Usia } \\
\text { 25-28tahun } \\
\text { 29-32tahun } \\
\text { 33-36tahun } \\
\text { 37-39 tahun }\end{array}$ & $\begin{array}{l}5 \\
8 \\
4 \\
1 \\
3\end{array}$ & $\begin{array}{l}16,7 \\
26,7 \\
13,3 \\
43,3\end{array}$ \\
\hline $\begin{array}{l}\text { Agama } \\
\text { Islam } \\
\text { Kristen }\end{array}$ & $\begin{array}{r}27 \\
3\end{array}$ & $\begin{array}{l}90 \\
10\end{array}$ \\
\hline $\begin{array}{c}\text { Suku } \\
\text { Jawa } \\
\text { Batak } \\
\text { Aceh } \\
\text { Minang }\end{array}$ & $\begin{array}{r}12 \\
10 \\
4 \\
4\end{array}$ & $\begin{array}{l}40,0 \\
33,3 \\
13,3 \\
13,3\end{array}$ \\
\hline $\begin{array}{c}\text { Umur Pertama Menikah } \\
\text { 18-20tahun } \\
\text { 21-23tahun } \\
\text { 24-26tahun } \\
\text { 27-29 tahun }\end{array}$ & $\begin{array}{r}6 \\
13 \\
6 \\
5\end{array}$ & $\begin{array}{l}20,0 \\
43,3 \\
20,0 \\
16,7\end{array}$ \\
\hline $\begin{array}{c}\text { Pemeriksaan SSK } \\
\text { Tampak Total }\end{array}$ & 30 & 100 \\
\hline $\begin{array}{c}\text { Hasil IVA } \\
\text { Negatif/ Serviks Normal Radang/ } \\
\text { Servisitis }\end{array}$ & $\begin{array}{r}27 \\
3\end{array}$ & $\begin{array}{l}90 \\
10\end{array}$ \\
\hline
\end{tabular}


Tabel 2. Efektivitas KIE terhadap pengetahuan WUS tentang kanker serviks dan tes IVA

\begin{tabular}{ccccc}
\hline Variabel & Mean & SD & $\begin{array}{c}\text { Beda } \\
\text { Mean }\end{array}$ & Nilai P \\
\hline Pre test & 14,57 & 3,633 & -9.03 & 0,001 \\
Post test & 23,60 & 1,589 & & 0,001 \\
& & & & \\
\hline
\end{tabular}

Berdasarkan data, mayoritas WUS berusia 37-39 tahun (43.3\%),beragama Islam (90\%), suku jawa (40\%),umur pertama menikah 21-23 tahun (43.3\%),melahirkan tiga kali (30\%), hasil tes IVA negatife (90\%) dan terdapat radang (10\%).

Berdasarkan pertanyaan yang paling banyak dijawab salah oleh WUS sebelum mendapat KIE adalah tentang usia terjadinya kanker serviks, penyebab kanker serviks, kanker serviks dapat diturunkan ke anak, ideal pelaksanaan tes IVA. Diperoleh data bahwa mayoritas pengetahuan WUS masih berada pada kategori cukup. Setelah dilakukan KIE, diperoleh data pertanyaan yang paling banyak belum dipahami WUS adalah manfaat $(5 \%)$ dan indikasi dilakukan test IVA (5\%), Dapat dinyatakan bahwa ada peningkatan pengetahuan WUS yaitu berada pada kategori baik.

\section{Pembahasan}

\section{Analisis Bivariat}

Berdasarkan uji Wilcoxon yang dilakukan diperoleh beda mean 9.03 dan nilai $\mathrm{P}=0.001$ $(<0.05)$ maka dapat disimpulkan metode KIE efektif dalam meningkatkan pengetahuan WUS tentang kanker serviks dan tes IVA. KIE adalah suatu upaya untuk menciptakan perilaku masyarakat yang kondusif untuk kesehatan.Tujuan dilaksanakannya KIE adalah meningkatkan pengetahuan,sikap dan tindakan tentang kanker serviks dan tes IVA t,sehingga responden terdorong untuk mau melakukan pemeriksaan IVA test. Kegiatan KIE yang dilakukan adalah KIE individu dengan menggunakan medialefleat.

Berdasarkan Hasil dari penelitian Ennawati, dkk (2014) menujukkan terdapat pengaruh pendidikan kesehatan dengan model Peer Group terhadap perilaku Ibu melakukan Deteksi Dini Kanker Serviks antara kelompok eksperimen dengan kelompok kontrol. Dengan statistik Perilaku ibu melakukan deteksi dini kanker serviks baik pada kelompok eksperimen Perilaku baik pada post test terdapat $27(62,8 \%)$, perilaku cukup 5 orang $(11,6 \%)$ dan kurang baik sebanyak 11 orang $(25,6 \%)$. sedangkan perilaku pada kelompok kontrol pada post test terjadi perubahan perilaku dari $34(79,1 \%)$ responden yang kurang mendukung berkurang menjadi 5 responden $(11,6 \%)$ yang berperilaku cukup, namun dijumpai adanya responden yang mendukung baik yaitu sebanyak 4 orang $(9,3 \%)$.

Dalam rangka pembinaan peningkatan perilaku kesehatan masyarakat, pendekatan KIE lebih tepat dilakukan. Intervensi dengan tatap muka langsung antara pihak penerima informasi dengan yang menyampaikan informasi merupakan intervensi dua arah yang lebih memungkinkan untuk menghasilkan perubahan. Pendekatan yang dilakukan adalah redundancy yaitu mempengaruhi target sasaran WUS dengan jalan mengulang-ulang pesan; canalizing yaitu mengubah pengetahuan, pemikiran, pendapat dan sikap mental target sasaran calon WUS; informatif yaitu mempengaruhi target sasaran WUS melalui kegiatan pendidikan kesehatan; persuasif yaitu komunikasi yang dipusatkan pada perubahan kesadaran atau sikap mental WUS.

Menurut penelitian Mulyati, dkk. (2015) dengan tujuan untuk mengetahui pengaruh pendidikan kesehatan melalui film terhadap sikap ibu pada tes IVA, didapatkan hasil terdapat pengaruh positif pendidikan kesehatan melalui film terhadap sikap ibu (nilai $\mathrm{P}<0,05$ ). Berdasarkan penelitian Saraswati (2011) mengatakan bahwa promosi kesehatan dapat meningkatkan pengetahuan tentang kanker serviks dan partisipasi wanita dalam program deteksi dini kanker serviks. Promosi kesehatan dengan menggunakan film memberikan hasil yang lebih baik dibandingkan dengan leaflet. Berdasarkan penelitian yang dilakukan Wahyuni 
(2011) mengatakan bahwa faktor yang paling dominan mempengaruhi perilaku deteksi dini kanker serviks adalah intervensi edukasi dengan nilai $\mathrm{p}=0,010$ dan OR 3,050.

\section{Kesimpulan dan Saran}

Metode KIE dapat meningkatkan pengetahuan WUS tentang kanker serviks dan manfaat tes IVA. Tes IVA yang dilakukan dapat mendeteksi radang dan tanda kanker servik pada WUS. Disarankan kepada WUS agar rutin melakukan IVA tes setiap tiga (3) tahun, dan kepada bidan disarankan agar rutin melakukan sosialisasi manfaat tes IVA serta memotivasi WUS untuk melakukannya.

\section{Ucapan terima kasih}

Terima kasih kami ucapkan kepada bapak Rektor USU, Wakil Rektor III dan Ketua LPPM USU yang telah mendukung pendanaan pelaksanaan kegiatan PkM ini dengan danaNON PNBP Universitas Sumatera Utarasesuai dengan Surat Perjanjian Penugasan Pelaksanaan Pengabdian kepada Masyarakat Program Mono Tahun Reguler. Tahun Anggaran 2019. Nomor: 327/UN5.2.3.2.1/PPM/2019, Tanggal 20 Mei 2019.

\section{Referensi}

[1] Ropitasari, Soetrisno, Mulyani S, Saddhono.K., (2014). Deteksi dini kanker leher rahim melalui tes IVA di PUSKESMAS JATEN II Kabupaten Karanganyar. Jurnal Fakultas Kedokteran Universitas Sebelas Maret; Vol. 3, No.1, November 2014

[2] Juandai D, Kesuma.H. (2015). Pemeriksaan Metode IVA (Inspeksi Visual Asam Asetat) untuk Pencegahan Kanker Serviks. Jakarta: Jurnal Kedokteran dan Kesehatan, Vol. 2, No. 2, April 2015: 169-174

[3] Wiyono S, Iskandar M. (2015). Inspeksi Visual Asam Asetat (IVA) Untuk Deteksi Dini Lesi PraKanker Serviks. www.jurnal Media Mediasiana Indonesia. Vol. 43, No. 3, tahun 2008:116-120.

[4] Mulyati., dkk. (2015). Pengaruh Media Film Terhadap Sikap Ibu Pada Deteksi Dini Kanker Serviks. Kemas. Jurnal Kesehatan Masyarakat. Vol 11, No 1. https://journal.unnes. ac.id/nju/index.php/kemas/article/view/3401.

[5] Wahyuni. S. (2011). Efektifitas Edukasi Metode Wish and Drive Terhadap Perilaku Deteksi Dini Kanker Serviks di Kecamatan Ngampel Kabupaten Kendala Jawa Tengah. Fakultas Ilmu Keperawatan Program Magister Ilmu Keperawatan. (Tesis).

[6] Dewi.L., dkk. (2014). Faktor - Faktor Yang Berhubungan Dengan Perilaku Wanita Usia Subur Dalam Deteksi Dini Kanker Serviks Dengan Metode Pemeriksaan Inspeksi Visual Asam Asetat (Iva) Di Wilayah Kerja Puskesmas Tanjung Hulu Pontianak Timur Tahun 2014.

[7] Ennawati. S. dkk. (2014). Pengaruh Pendidikan Kesehatan dan Model Peer Group terhadap Perilaku ibu melakukan deteksi dini kanker serviks. Fakultas Ilmu Kesehatan Universitas Muhammadiyah Surakarta. Program Studi Keperawatan Fakultas Kedokteran Universitas Tanjungpura Pontianak.

[8] Rahmadyanti. (2015). Pengetahuan WUS tentang deteksi dini kanker serviks dengan metode IVA test di Cipinagn Besar Utara. Jatinegara. Jurnal Permata Medika Pasien Kanker. Volume 4 No 1, Juli 2015.

[9] Saraswati. K. L. (2011). Pengaruh Promosi Kesehatan Terhadap Pengetahuan Tentang Kanker Serviks dan Partisipasi Wanita Dalam Deteksi Dini Kanker Serviks. Program Pascasarjana Universitas Sebelas Maret Surakarta (Tesis)

[10] Wowiling.G.J(2015). Komunikasi Informasi dan Edukasi (KIE) sebagai bentuk sosialisasi program Keluarga Berencana (KB) di Kelurahan TingkuluKecamatan Wanea Manado. Jurnal 'Acta Diurna”, Vol. IV, No.1, tahun 2015. 